\title{
Platelet derived malonyldialdehyde production in patients with thalassaemia major
}

\author{
AP JEWELL, RE MARCUS \\ From the Department of Haematology, University College Hospital, London WC1E 6AU
}

SUMMARY Malonyldialdehyde, a product of membrane lipid peroxidation, was measured in the platelets of 16 normal subjects after stimulation with a variety of aggregating and stimulating agents. Nethylmaleimide and hydrogen peroxide generated the largest amounts of malonyldialdehyde. These agents were used to stimulate platelets from 11 patients with thalassaemia major suffering from iron overload due to repeated transfusion. Mean malonyldialdehyde concentrations were the same in normal subjects as in thalassaemic patients, but high concentrations were recorded in patients with severe iron overload. There was a highly significant correlation between malonyldialdehyde and serum ferritin concentrations in all thalassaemic patients. Platelet derived malonyldialdehyde may be a useful test of continuing membrane damage in patients with iron overload.

Lipid peroxidation of cell membranes is associated with a number of pathological conditions, such as radiation damage to the lungs, liver injury, atherosclerosis, and thrombosis ${ }^{-4}$ and many inflammatory processes. ${ }^{56}$ Malonyldialdehyde, a stable secondary product of lipid peroxidation, ${ }^{78}$ can be measured after oxidant stress. ${ }^{9}$ With this technique red cells have been shown to be more susceptible to autoxidation in autoimmune haemolytic anaemia and $\beta$-thalassaemia major. ${ }^{10}$ Iron salts are among the most potent catalysts of lipid peroxidation, ${ }^{11} 12$ and high red cell malonyldialdehyde concentrations found in patients who have had multiple transfusions may reflect the damage to other organs caused by excess iron. In patients with $\beta$-thalassaemia major it is difficult to correlate red cell malonyldialdehyde concentrations with membrane damage in other tissues as many of these cells are transfused, producing inappropriately low values, and thalassaemic red cell membranes contain large amounts of lipid susceptible to autoxidation compared with normal cells. ${ }^{13}$

Malonyldialdehyde is also formed in platelets during the non-enzymatic peroxidation of polyunsaturated fatty acids ${ }^{14}$ and enzymatically during prostaglandin production. ${ }^{15}$ There has been one previous report of abnormal platelet function in $\beta$-thalassaemia major. ${ }^{16}$ We have therefore investigated malonyldialdehyde generation in the platelets of normal subjects and repeatedly transfused

Accepted for publication 6 June 1984 patients with $\beta$-thalassaemia major on exposure to oxidant stress with hydrogen peroxide and on activation with nethylmaleimide, an agent used to assess platelet activation in vitro. ${ }^{17} 18$ We have also correlated platelet malonyldialdehyde production with the degree of iron overload assessed by serum ferritin.

\section{Material and method}

Twenty millilitres of venous blood was collected into $3.13 \%$ sodium citrate and centrifuged at $150 \mathrm{~g}$ for $15 \mathrm{~min}$ at $20^{\circ} \mathrm{C}$. The supernatant platelet poor plasma was then inverted for $2 \mathrm{~min}$ to remove all plasma, and the platelet buttons were resuspended in $0.9 \mathrm{ml}$ of phosphate buffered saline (PBS). Malonyldialdehyde generation was measured after stimulation with adenosine diphosphate, adrenaline, collagen, ristocetin, nethylmaleimide, and hydrogen peroxide.

To four of the tubes we added $100 \mu$ l of one of the stimulating agents and to the fifth we added $100 \mu \mathrm{l}$ of PBS as a blank. The suspensions were then incubated for $60 \mathrm{~min}$ at $37^{\circ} \mathrm{C}$ in a waterbath. After incubation $1 \mathrm{ml}$ of the 2-thiobarbituric acid solution was added to each tube, which was vortex mixed to terminate the reaction and then incubated for $30 \mathrm{~min}$ at $80^{\circ} \mathrm{C}$. The tubes were then removed, cooled on ice, and centrifuged at $2000 \mathrm{~g}$ for $15 \mathrm{~min}$ at $4^{\circ} \mathrm{C}$. The optical density of the supernatant was read at 532 nm against the appropriate blank, and the concentration of malonyldialdehyde was calculated as follows: 
nmol malonyldialdehyde per $10^{\circ}$ platelets $=\frac{\text { A.Vf }}{\text { N.Vi.E }} \times 10^{9}$

where $A=$ optical density at $532 \mathrm{~nm}, \mathrm{Vf}=$ final volume $(1 \mathrm{ml}), \mathrm{Vi}=$ initial volume $(0.9 \mathrm{ml}), \mathrm{N}=$ platelet count (platelet rich - platelet poor plasma), and $E=$ molar extinction coefficient of malonyldialdehyde $\left(1.55 \times 10^{5}\right)$.

\section{PATIENTS}

Malonyldialdehyde concentrations were measured in 16 healthy volunteer subjects (age range 18-30 years) and 11 patients with transfusion dependent thalassaemia major (age range 16-25 years) who were attending the thalassaemia clinic at University College Hospital. Serum ferritin concentrations ${ }^{19}$ were measured in samples taken on the same day as the malonyldialdehyde measurements were performed.

\section{Results}

Malonyldialdehyde generation from platelets was measured in 16 normal volunteers after stimulation with one of the above agents. These induced different concentrations in normal subjects: adenosine diphosphate, adrenaline and collagen induced low concentrations; ristocetin gave higher values; and hydrogen peroxide and nethylmaleimide induced the highest values (Table 1).

Nethylmaleimide and hydrogen peroxide were then used to generate malonyldialdehyde in 11 patients with $\beta$-thalassaemia major who had had multiple transfusions. Both agents stimulated malonyldialdehyde production in all patients and there was no significant difference between mean malonyldialdehyde concentrations derived from thalassaemic and normal platelets, but the range of values for the patients with thalassaemia was increased (Table 2).

The level of nethylmaleimide and hydrogen peroxide stimulated malonyldialdehyde production was then compared with serum ferritin concentrations in 10 patients (Figure). There was a highly significant correlation between malonyldialdehyde concentrations and serum ferritin concentrations when either stimulant was used: for nethylmaleimide $r=0.84(p<0.001)$ and for hydrogen peroxide $r=0.90(p<0.01)$. Three patients with substantially raised serum ferritin concentrations had malonyldialdehyde values outside the normal range ( $> \pm 2$ SD for 16 normal subjects). These patients were all heavily iron overloaded and complied poorly with desferrioxamine. All had strikingly abnormal liver function tests, were heavily pigmented, and two had signs of compromised cardiac function.
Table 1 Effects of various stimulating agents on malonyldialdehyde generation from platelets from 16 normal subjects

\begin{tabular}{ll}
\hline $\begin{array}{l}\text { Stimulating agent } \\
\text { (concentration) }\end{array}$ & $\begin{array}{l}\text { Malonyldialdehyde concentration } \\
\text { (nmol/10 } 0^{9} \text { platelets) } \pm 2\end{array}$ \\
\hline Nethylmaleimide $(1 \mathrm{mM})$ & $1 \cdot 05 \pm 0 \cdot 25^{*}$ \\
Hydrogen peroxide $(10 \mathrm{mM})$ & $0 \cdot 85 \pm 0 \cdot 33$ \\
Ristocetin $(12 \mathrm{mg} / \mathrm{ml})$ & $0 \cdot 46 \pm 0 \cdot 04$ \\
ADP $(10 \mu \mathrm{m})$ & $0 \cdot 14 \pm 0 \cdot 02$ \\
Adrenaline $(1 \mathrm{mg} / \mathrm{ml})$ & $0 \cdot 08 \pm 0 \cdot 02$ \\
Collagen $(1 \mu \mathrm{g} / \mathrm{ml})$ & $0 \cdot 05 \pm 0 \cdot 01$ \\
& $\mathrm{n}=16$ \\
\hline
\end{tabular}

${ }^{*}$ Values given as mean $\pm 2 \mathrm{SD}$

Table 2 Malonyldialdehyde (nmol/10 $0^{9}$ platelets) generated from platelets from patients with $\beta$-thalassaemia major

\begin{tabular}{lll}
\hline Patient no & $\begin{array}{l}\text { Nethylmaleimide } \\
(1.0 \mathrm{mM})\end{array}$ & $\begin{array}{l}\text { Hydrogen peroxide } \\
(10 \mathrm{mM})\end{array}$ \\
\hline 1 & $1.09 \pm 0.06^{*}$ & $0.78 \pm 0.15$ \\
2 & $1.78 \pm 0.11$ & $1.10 \pm 0.23$ \\
3 & $2.61 \pm 0.02$ & $1.75 \pm 0.11$ \\
4 & $0.66 \pm 0.05$ & $\mathrm{ND}$ \\
5 & $1.15 \pm 0.13$ & $\mathrm{ND}$ \\
6 & $0.44 \pm 0.04$ & $0.62 \pm 0.32$ \\
7 & $0.25 \pm 0.03$ & $0.10 \pm 0.07$ \\
8 & $1.77 \pm 0.04$ & $\mathrm{ND}$ \\
9 & $0.57 \pm 0.14$ & $\mathrm{ND}$ \\
10 & $\mathrm{ND}$ & $0.23 \pm 0.09$ \\
11 & $0.40 \pm 0.02$ & $0.34 \pm 0.17$ \\
Normal subjects & $1.05 \pm 0.25$ & $0.85 \pm 0.33$ \\
(mean) & & \\
Thalassaemia major & $1.07 \pm 0.73$ & $0.70 \pm 0.53$ \\
(mean) & & \\
\hline
\end{tabular}

*Values given as mean $\pm 2 \mathrm{SD}$.

$\mathrm{ND}=$ not done.

\section{Discussion}

In this study we assessed the ability of several platelet stimulating agents to induce malonyldialdehyde release from the platelets of normal subjects and of patients suffering from thalassaemia major. In platelets from patients with $\beta$-thalassaemia, mean malonyldialdehyde concentrations were normal, but there was a close correlation between platelet

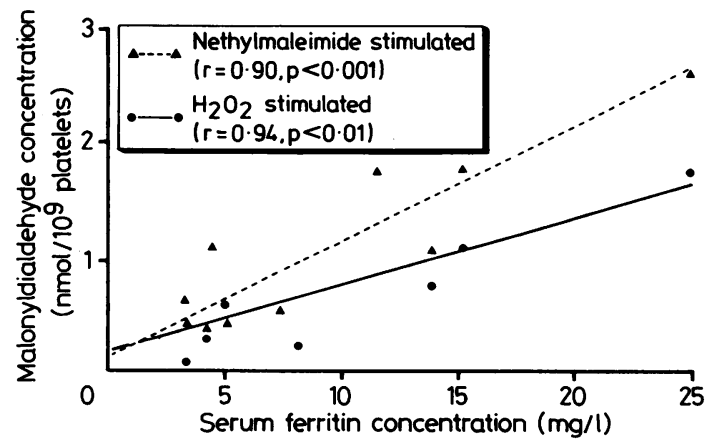

Concentrations of platelet derived malonyldialdehyde and serum ferritin in patients with thalassaemia major. 
malonyldialdehyde values and serum ferritin concentrations whether hydrogen peroxide or nethylmaleimide was used as the stimulating agent. The highest malonyldialdehyde concentrations were recorded in patients who not only had considerably raised serum ferritin concentrations but also had other signs of iron overload. As platelet associated malonyldialdehyde provides a measure of lipid peroxidation of cell membranes, the raised concentrations found in the most heavily iron overloaded patients may therefore reflect increased iron mediated cell membrane damage; such high values may be associated with increased quantities of free iron or that loosely bound in the postulated toxic iron pool. ${ }^{20}$

Serum ferritin concentrations closely correlate with total and hepatic iron stores, ${ }^{21}$ and in the well chelated, iron overloaded patient much of the transfused iron is sequestered in a relatively inert form ${ }^{22} 23$ and plays a comparatively small part in continuous iron mediated membrane damage. In grossly iron overloaded patients, however, or in those patients who comply poorly with desferrioxamine treatment, there may be sufficient iron in an active form to cause increased membrane lipid peroxidation and consequent tissue damage. High concentrations of platelet malonyldialdehyde may be recorded only in these patients, and our data suggest that values outside the normal range are indeed obtained in patients who show signs of iron toxicity in addition to raised serum ferritin concentrations.

Clinical improvement in iron overloaded thalassaemic patients may be brought about by increasing the dosage of desferrioxamine ${ }^{24}$ and deterioration may follow administration of large amounts of vitamin $\mathrm{C}_{, 25}$ with comparatively minor changes in serum ferritin; this suggests that the serum ferritin concentration is not an adequate measure of continuing organ damage.

We conclude that the use of stimulated platelet malonyldialdehyde concentrations provides a useful, simple measure of lipid peroxidation and consequent cell membrane damage in chronically iron overloaded patients and that serial measurements may be a useful guide to clinical progress.

We thank Professor ER Huehns for permission to study patients under his care and Mrs Jean De Luca for secretarial assistance.

\section{References}

' Tappel AL. Lipid peroxidation damage to cell components. Fed Proc 1973; 32: 1870-4.

${ }^{2}$ Plaa GL, Witsch $\mathrm{H}$. Chemicals, drugs and lipid peroxidation. Ann Rev Pharmacol Toxicol 1976;16:125-41.

${ }^{3}$ Aznar J, Santos MT, Valles J, Sala J. Serum malondialdehydelike material (MDA-LM) in acute myocardial infarction. $J$
Clin Pathol 1983;36:712-5.

4 Santos MT, Valles J, Aznar J, Vilches J. Determination of the plasma malondialdehyde-like material (MDA-LM) and its clinical application in stroke patients. J Clin Pathol 1980;33:973-6.

${ }^{5}$ Muus P, Bonta IL, Oudsten SA. Plasma levels of malondialdehyde, a product of cyclo oxygenase dependent and independent lipid peroxidation in rheumatoid arthritis: A correlation with disease activity. Prostaglandins in Medicine 1979;2:63-5.

${ }^{\circ}$ Bragt PC, Schenkelaars EPM, Bonta IL. Dissociation between prostaglandin and malondialdehyde formation in plasma and liver during granulomatous inflammation in the rat. Prostaglandins in Medicine 1979; 2:51-61.

' Placer ZA, Cushman LL, Johnson BC. Estimation of product of lipid peroxidation (malondialdehyde) in biochemical systems. Analyt Biochem 1966;16:359-64.

* Porter NA. Prostaglandin endoperoxides. In: Prior WA, ed. Free radicals in biology. New York: Academic Press, 1980:261-94.

${ }^{4}$ Stocks J, Dormandy TL. The autoxidation of human red cell lipids induced by hydrogen peroxide. $\mathrm{Br} J$ Haematol 1971;20:95.

${ }^{10}$ Stocks J, Offerman EL, Modell CB, Dormandy TL. The susceptibility to autoxidation of human red cell lipids in health and disease. Br J Haematol 1972;23:713-24.

"Tien M, Sringen A, Aust SD. Superoxide-dependent lipid peroxidation. Fed Proc 1981; 40:179.

12 Heys AD, Dormandy TL. Lipid peroxidation in iron overloaded spleens. Clin Sci 1981;60:295.

${ }^{13}$ Rachmilewitz EA, Lubin BH, Shohet SB. Lipid membrane peroxidation in $\beta$-thalassaemia major. Blood 1976;47:495504.

is Pryor WA, Stanley JP. A suggested mechanism for the production of malondialdehyde during the autoxidation of polyunsaturated fatty acids. Nonenzymatic production of prostaglandin endoperoxides during autoxidation. J Org Chem 1975; 40:3615-7.

is Smith JB, Ingerman CM, Silver MJ. Malondialdehyde formation as an indicator of prostaglandin production by human platelets. J Lab Clin Med 1976;88:167.

${ }^{10}$ Eldor A. Abnormal platelet functions in $\beta$-thalassaemia. Scand $J$ Haematol 1978;20:447-52.

${ }^{17}$ Okuma M, Steiner M, Baldini M. Studies on lipid peroxides in platelets I. Method of assay and effect of storage. J Lab Clin Med 1970; 75:283-96.

1* Okuma M, Steiner M, Baldini M. Studies on lipid peroxides in platelets. II. Effect of aggregating agents and platelet antibody. J Lab Clin Med 1971;77:728-42.

${ }^{19}$ Worwood M. Serum ferritin. In: Cook JD, ed. Methods in haematology, vol 1. New York: Churchill Livingstone, 1980.

${ }^{20}$ Hershko C, Graham G, Bates GW, Rachmilewitz EA. Nonspecific serum iron in thalassaemia major: an abnormal serum fraction of potential toxicity. Br J Haematol 1978; 40:255-63.

${ }^{21}$ Letsky E, Miller F, Worwood M, Flynn DM. Serum ferritin in regularly transfused children with thalassaemia.J Clin Pathol 1974;27:652-5.

${ }^{22}$ Cohen A, Cohen I, Schwartz E. Scurvy and altered iron stores in thalassaemia. $N$ Engl J Med 1980;304: 158-60.

${ }^{23}$ Nienhuis A. Vitamin C and iron. N Engl J Med 1980;304:170-1.

${ }^{24}$ Marcus RE, Davies SC, Bantock HM, Underwood SR, Walton S, Huehns ER. Desferrioxamine to improve cardiac function in iron-overloaded patients with thalassaemia major. Lancet 1984; i: 392-3.

${ }^{25}$ Henry W. Echocardiographic evaluation of the heart in thalassaemia major. In: Nienhuis AW (moderator). Thalassaemia major: molecular and clinical aspects. Ann Int Med 1979;91:892-4.

Requests for reprints to: Dr RE Marcus, MRC Leukaemia Unit, Royal Postgraduate Medical School, DuCane Road, London W12 0HS. 